\title{
EFFECTIVENESS OF GRAPE SEED EXTRACT-BASED INTRACANAL DRESSINGS AGAINST Enterococcus Faecalis AND ITS INFLUENCE ON DENTIN MICROHARDNESS AND BOND STRENGTH OF FILLING MATERIAL
}

\author{
EFICÁCIA DE MEDICAMENTOS INTRACANAIS À BASE DE EXTRATO DE \\ SEMENTE DE UVA CONTRA O Enterococcus Faecalis E SUA INFLUENCIA NA \\ MICRO-DUREZA DA DENTINA E NA RESISTÊNCIA DE UNIÃO DO MATERIAL \\ OBTURADOR
}

\section{Matheus Albino SOUZA ${ }^{1}$; Daniel de Lima DALLA LANA ${ }^{2}$; Amália PLETSCH ${ }^{3}$; Huriel Scartazzini PALHANO ${ }^{1}$; Juliane BERVIAN ${ }^{4}$; João Paulo de CARLI ${ }^{5}$; Doglas CECCHIN ${ }^{1}$}

1. School of Dentistry, Department of Endodontics, University of Passo Fundo, Passo Fundo, RS, Brazil; 2. School of Dentistry, University of Passo Fundo, Department of Endodontics, Passo Fundo, RS, Brazil; 3. School of Dentistry, University of Passo Fundo, Department of Endodontics, RS, Brazil; 4. School of Dentistry, Department of Pediatric Dentistry, University of Passo Fundo, Passo Fundo, RS, Brazil. 5. University of Passo Fundo, School of Dentistry, Department of Oral Medicine, RS, Brazil. joaodecarli@upf.br.

\begin{abstract}
The aim of this study was to evaluate the effectiveness of grape seed extract (GSE)based intracanal dressings against Enterococcus faecalis (E. faecalis) and its influence on dentin microhardness and bond strength of the filling material. The root canals of 126 human teeth were distributed into three test groups: antimicrobial activity (60 teeth), dentin microhardness (30 teeth) and bond strength (36 teeth). In all three groups, specimens were subdivided into six groups, according to intracanal dressing protocols: G1 distilled water (DW); G2 - 2\% chlorhexidine gel (CHX); G3 - calcium hydroxide $\left(\mathrm{Ca}[\mathrm{OH}]_{2}\right)+\mathrm{DW}$; G4 $\mathrm{GSE}+\mathrm{DW}$; G5 $-\mathrm{Ca}(\mathrm{OH})_{2}+\mathrm{CHX}$; G6 - GSE $+\mathrm{CHX}$. The counting of colony-forming units (CFUs), the Vickers microhardness tester and the push-out test were performed to evaluate the antimicrobial activity, dentin microhardness and bond strength, respectively. Specific statistical analysis was performed for each evaluation $(\alpha=5 \%)$. The greatest bacterial reduction was observed in $\mathrm{G} 5\left(\mathrm{Ca}[\mathrm{OH}]_{2}+\mathrm{CHX}\right)$ and $\mathrm{G6}(\mathrm{GSE}+\mathrm{CHX})(\mathrm{p}<0.05)$. There was no statistically significant difference among groups in the dentin microhardness evaluation $(\mathrm{p}<0.05)$. The highest bond strength in the immediate evaluation was observed in G4 (GSE+DW) and G6 (GSE+CHX), whereas the highest bond strength after 12 months of storage was observed in $\mathrm{G} 2(\mathrm{CHX}), \mathrm{G} 3\left(\mathrm{Ca}[\mathrm{OH}]_{2}+\mathrm{DW}\right)$, G4 (GSE+DW), and G6 (GSE+CHX) $(\mathrm{p}<0.05)$. After the storage period, bond strength was increased in G2 $(\mathrm{CHX})$ and $\mathrm{G} 3\left(\mathrm{Ca}[\mathrm{OH}]_{2}+\mathrm{DW}\right)$, and remained unchanged in $\mathrm{G} 4(\mathrm{GSE}+\mathrm{DW})$ and $\mathrm{G} 6(\mathrm{GSE}+\mathrm{CHX})(\mathrm{p}<0.05)$. GSE-based intracanal dressings have antimicrobial potential against E. faecalis, have no influence in dentin microhardness and preserve the high bond strength of filling materials for root dentin over time.
\end{abstract}

KEYWORDS: Antimicrobial activity. Bond strength. Grape seed extract. Intracanal dressing. Microhardness.

\section{INTRODUCTION}

Conventional chemo-mechanical preparation by using irrigants and endodontic instruments does not promote complete neutralization of microorganisms during endodontic therapy (SOUZA et al., 2018). This occurs due to the presence of resistant bacteria in the endodontic microbiota that colonize root canals and persist after decontamination procedures (TENNERT et al., 2014). Furthermore, due to the anatomical complexity of the root canal system, microorganisms, inorganic and organic components cannot always be reached by chemical auxiliary substances, and some areas of the main root canal are also not reached by endodontic instruments (VAUDT et al., 2009). Thus, additional antimicrobial strategies are necessary, such as intracanal dressings, in order to aid in the decontamination of the root canal system.

Calcium hydroxide $\left(\mathrm{Ca}[\mathrm{OH}]_{2}\right)$ is the most used intracanal dressing in the endodontic therapy, due to its ability to neutralize bacterial endotoxins, induce mineralization on periapical tissues and biocompatibility (LEONARDO et al., 2006). Furthermore, $\mathrm{Ca}(\mathrm{OH})_{2}$-based intracanal dressings act as physical barrier, inhibiting the flow of nutrients and bacterial recolonization (SIQUEIRA et 
Effectiveness...

al., 1999). However, microorganisms such as Enterococcus faecalis (E. faecalis) demonstrate resistance to $\mathrm{Ca}(\mathrm{OH})_{2}$ (SATHORN; PARASHOS; MESSER, 2007). Finally, $\mathrm{Ca}(\mathrm{OH})_{2}$-based intracanal dressings decrease the root fracture resistance (YASSEN et al., 2013), increase the root dentin microhardness (YASSEN et al., 2013) and present negative effect on the bond strength of resin-based endodontic sealers (GUIOTTI et al., 2014). Thus, it is important to identify new alternatives that contribute in a better way to the decontamination of the root canal system, with no harmful effects to root dentin and root canal filling.

Currently, there are a growing number of studies testing natural substances in the endodontic field, since literature has shown antimicrobial potential against endodontic pathogens for these substances, such as grape seed extract (GSE) (CECCHIN et al., 2015; SOUZA et al., 2017). GSE represents a natural compound, which has proanthocyanidins (PACs) in its composition. PACs are recognized to present therapeutic activities, providing antioxidant, antimutagenic and antibacterial effects (FURIGA; ROQUES; BADET, 2014). In addition, PACs are known to enhance the dentine biomechanical properties and biostability (VIDAL et al., 2014). However, previous studies have reported the use of GSE as chemical auxiliary substance or final decontamination protocol (CECCHIN et al., 2015; SOUZA et al., 2017). There are no studies in literature regarding the use of GSE as intracanal dressing, evaluating the antimicrobial effectiveness and the influence on dentin mechanical properties and bond strength of the filling material.

The purpose of this study was to evaluate, in vitro, the effectiveness of GSE-based intracanal dressings against $E$. faecalis and its influence on dentin microhardness and bond strength of filling materials. The present hypotheses were that GSEbased intracanal dressings (i) promote effective reduction of $E$. faecalis, (ii) do not interfere in dentin microhardness, and (iii) improve the bond strength of the filling material.

\section{MATERIALS AND METHODS}

\section{Ethical aspects}

This study was approved by the local ethics committee (Passo Fundo, RS, Brazil) (protocol 2.033.198).

\section{Specimen acquisition and preparation}

One hundred and twenty six extracted single-rooted human teeth were obtained from the
SOUZA, M. A. et al.

Biobank of the School of Dentistry University of Passo Fundo. Only teeth with a single canal, complete root apex, similar buccal-lingual / mesiodistal dentin thickness and absence of root curvature were included in the present study. The teeth that did not have these characteristics were not included in the present study. Dental crowns were sectioned at the cement-enamel junction using a rotating diamond saw so that all roots remained with length of $15 \mathrm{~mm}$. The cervical third was prepared using Largo drill \#3 (Dentsply-Maillefer, Ballaigues, Switzerland). The working length was established by inserting a K-file \#10 (Dentsply-Maillefer) into the canal until its tip was visualized at the apical foramen. From this measurement, $1 \mathrm{~mm}$ was subtracted, thus establishing the working length. Root canals were enlarged to the working length using the ProTaper system (Dentsply Tulsa Dental Specialties, Johnson City, TN, USA), following the sequence S1 to F3. ProTaper files were used in a 16:1 reduction handpiece with controlled torque under constant rotation of $300 \mathrm{rpm}$, inserted into the root canal in the crown-apex direction, performing a smooth digital back-and-forth movement. The irrigant solution was distilled water (DW) (Natupharma, Passo Fundo, RS, Brazil), which was replaced with each change of instrument. Firstly, 1 $\mathrm{mL}$ of DW was inserted into the root canal with extravasation to root canal entrance. The S1 file worked until the WL and after that irrigation with 5 $\mathrm{mL}$ of DW was performed. This step was repeated with S2, F1, F2 and F3 files, totalizing $30 \mathrm{~mL}$ of DW that were used in each canal of each specimen.

After instrumentation, root canals were irrigated with $3 \mathrm{~mL}$ of 17\% EDTA (Natupharma, Passo Fundo, RS, Brazil), which remained for 1 minute into the root canal in order to remove the smear layer. Then, root canals were irrigated with 5 $\mathrm{mL}$ of DW again and dried using suction cannula. The 126 roots were randomly divided into three experimental test groups, as follows: 60 roots were used for antimicrobial activity evaluation, 30 roots for microhardness evaluation and 36 roots for bond strength evaluation. The sample size for each method was based in previous studies that also evaluated antimicrobial activity of antimicrobial strategies (SOUZA et al., 2017) and its influence on dentin microhardness (LYSAGHT; DEBELLIS, 1969) and bond strength (CECCHIN et al., 2015).

\section{Antimicrobial activity evaluation}

The 60 roots had its apical foramen sealed with composite resin. Each root was fixed with Putty-C Silicone for Impression (Silon2APS Dentsply, Petrópolis, RJ, Brazil) in a plastic micro- 
Effectiveness...

tube (Axygen Inc, Union City, CA, USA), so that it remained upright with the cervical portion facing upwards. Then, all roots were sterilized at $120^{\circ} \mathrm{C}$ in autoclave (Dabi Atlante, Ribeirão Preto, SP, Brazil) for $30 \mathrm{~min}$. After sterilization, six teeth were randomly submitted to sterilization control. Sterile paper point \#30 (Tanari, Manucapuru, AM, Brazil) was placed in contact with the root canal walls for 30 seconds and individually transported to plastic microtube containing $1 \mathrm{ml}$ of $0.9 \%$ saline solution (Basso, Caxias do Sul, RS, Brazil). The material was homogenized and an aliquot of $100 \mu \mathrm{L}$ of saline solution was cultivated on blood agar after five minutes. Samples were incubated at $37{ }^{\circ} \mathrm{C}$ for 48 hours, in order to verify bacterial growth. Samples did not show any bacterial growth.

Subsequently, a $100-\mu \mathrm{L}$ aliquot of $E$. faecalis culture (ATCC 19433) was inoculated into the root canal of each specimen. The remaining volume was completely filled with sterile brainheart-infusion (BHI) broth (Acumedia - Neogen, Lansing, MI, USA). The E. faecalis culture was maintained for 14 days, promoting bacterial growth. The BHI broth was replaced every 48 hours. Once a week, an aliquot of BHI obtained from six teeth randomly selected was submitted to Gram staining and cultured on blood agar, followed by catalase and esculin tests, in order to verify the absence of contamination with other microorganisms. This fact was detected, obtaining pure of E. faecalis culture after 14 days.

After contamination, the 60 specimens were irrigated with $5 \mathrm{~mL}$ of DW and randomly divided into six groups $(\mathrm{n}=10)$ according to the intracanal dressing: G1 - DW (negative control); G2 - 2\% chlorhexidine gel $(\mathrm{CHX}) ; \mathrm{G} 3-\mathrm{Ca}(\mathrm{OH})_{2}+\mathrm{DW} ; \mathrm{G} 4-$ $\mathrm{GSE}+\mathrm{DW} ; \mathrm{G} 5-\mathrm{Ca}(\mathrm{OH})_{2}+\mathrm{CHX}$; and $\mathrm{G} 6$ GSE + CHX. The first specimen was chosen randomly from all specimens and assigned to group 1 , the second specimen to group 2, and so on to group 6 . The distribution was repeated until each group presented the complete number of specimens.

In G1 (DW) and G2 (CHX), the intracanal dressing was inserted with a $3 \mathrm{~mL}$ disposable syringe (Descarpack, São Paulo, SP, Brazil) and a 30 gauge needle (Navi-Tip - Ultradent, South Jordan, UT, USA), until the root canal was completely filled. In $\mathrm{G} 3\left(\mathrm{Ca}[\mathrm{OH}]_{2}+\mathrm{DW}\right)$ and $\mathrm{G} 4$ (GSE+DW), the intracanal dressing was obtained from mixing $0.1 \mathrm{~g}$ of the test substance powder and $100 \mu 1$ of DW. After the paste was obtained, root canals were completely filled with the respective intracanal dressing using Lentulo drill (DentsplyMaillefer, Ballaigues, Switzerland), which was positioned $3 \mathrm{~mm}$ short of the working length. In G5
$\left(\mathrm{Ca}[\mathrm{OH}]_{2}+\mathrm{CHX}\right)$ and $\mathrm{G} 6 \quad(\mathrm{GSE}+\mathrm{CHX})$, the intracanal dressing was obtained from mixing $0.1 \mathrm{~g}$ of the test substance powder and $100 \mu \mathrm{l}$ of CHX. After the paste was obtained, root canals were completely filled with the respective intracanal dressing in the same way as that described for G3 and G4.

The 60 specimens were sealed with provisional restorative material (Cavitec - Caitthec, Rio do Sul, SC, Brazil) and stored for 14 days at 37 ${ }^{\circ} \mathrm{C}$ under humidity. After 14 days, the provisional restoration and intracanal dressing were removed by using \#1012 drill (Dentsply-Maillefer, Ballaigues, Switzerland) and irrigation with $10 \mathrm{~mL}$ of $\mathrm{DW}$ respectively.

Microbiological analysis was performed in two stages: initial sample (S1) - after contamination and before intracanal dressing protocols; and final sample (S2) - after 14 days of storage and removal of intracanal dressing protocols. In both stages, root canals were filled with sterile saline solution. Sterile K-file \#30 (Dentsply-Maillefer) was inserted at the working length, promoting contact with the root canal walls for 30 seconds. Sterile absorbent paper point \#30 (Tanari) was placed into the root canal in the same way for 30 seconds, after which, it was transferred to tube containing $450 \mu \mathrm{L}$ of sterile saline solution. The material was homogenized and diluted to $1 \times 10^{-3}$. Aliquots of $100 \mu \mathrm{L}$ of the solution and all dilutions were cultivated on the blood agar surface in duplicate. Samples were incubated for $18-24 \mathrm{~h}$ at $37{ }^{\circ} \mathrm{C}$. The number of colony-forming units (CFUs) was then counted on plates.

The effectiveness of intracanal dressing protocols was analyzed according to the percentage reduction of E. faecalis from initial (S1) and final (S2) samples. All procedures were performed under aseptic conditions in a laminar flow chamber.

\section{Microhardness evaluation}

After obtaining specimens and removal of dental crowns, two longitudinal grooves were produced in the external root surface of each of the 30 roots without reaching the canal space, using a diamond disc. Chemo-mechanical preparation was performed as previously described in the antimicrobial activity evaluation. The 30 specimens were randomly divided into six groups (5 roots per group) and submitted to the same intracanal dressing protocols, as previously described in the antimicrobial activity evaluation.

After 14 days, the provisional restoration and intracanal dressing were removed using \#1012 drill (Dentsply-Maillefer) and irrigation with $10 \mathrm{~mL}$ of DW respectively. Roots were split into two 
Effectiveness...

halves with hammer and chisel, providing 2 halves of each root and resulting in 10 specimens per group $(n=10)$.

Roots were embedded in self-curing acrylic resin held in plastic rings. The coronal portion of each segment was ground with carborundum disks (300, 600, and 1200 grade) under cooling and then polished using diamond paste. Microhardness measurements were performed on each section at $500 \mu \mathrm{m}$ from the pulp-dentin interface, and two other indentations were made at distance of $200 \mu \mathrm{m}$ from each other. At each depth, one indentation was made using 10-g load perpendicularly oriented to the indentation surface for 15 seconds. Measurements were performed with Knoop Microhardness Tester (HMV 2000 - Shimadzu, Kyoto, Japan). The dentin microhardness value for each specimen was obtained as the average of the results for three indentations.

\section{Bond strength evaluation}

After obtaining specimens and removal of dental crowns, chemo-mechanical preparation was performed in each one of 36 remaining roots, as previously described in the antimicrobial activity evaluation. The 36 specimens were randomly divided into six groups (6 roots per group) and submitted to the same intracanal dressing protocols, as previously described in the antimicrobial activity evaluation. After 14 days, provisional restoration and intracanal dressing were removed using \#1012 drill (Dentsply-Maillefer) and irrigation with $10 \mathrm{~mL}$ of DW respectively. Then, root canals were dried with suction cannula and absorbent paper points.

Root canals were filled by lateral compaction using gutta-percha points and AH Plus endodontic sealer (Dentsply Tulsa Dental Specialties). Excess filling material was removed by cutting with \#2 heated plugger (SS White Duflex, Rio de Janeiro, RJ, Brazil). The 6 specimens of each group were randomly divided into 2 subgroups (3 roots per subgroup), according to their storage period: 21 days and 12 months of storage, being immersed in DW at $37^{\circ} \mathrm{C}$.

In both evaluation periods, each root was transversely sectioned from the root canal entrance into 1-mm-thick discs in a metallographic cutter with diamond disk at speed of $350 \mathrm{rpm}$ under cooling. The first disc was discarded and the next five root discs were selected from each root, totaling 15 specimens per group $(n=3 \times 5=15)$. Each disc was submitted to the push-out test in a mechanical testing machine (EMIC DL 2000 - São José dos Pinhais, PR, Brazil) at speed of $1 \mathrm{~mm} / \mathrm{min}$, until displacement of the filling material. Care was taken to ensure that the contact between the punch tip and the filling material occurred over the most extended area as possible to avoid the notching effect of the punch tip on the filling material surface. Furthermore, the punch tip was centralized in the root canal and positioned to contact only the filling material without stressing the surrounding root canal walls. The force required to displace the material from the root canal was recorded in newtons $(\mathrm{N})$. To express the bond strength in megapascals, the load at failure recorded in $\mathrm{N}$ was divided by the area $\left(\mathrm{mm}^{2}\right)$ of the filling material interface. To calculate the bonding area, the formula $\pi(\mathrm{R}+\mathrm{r})\left[(\mathrm{h})^{2}+(\mathrm{R}-\right.$ $\left.r)^{2}\right]^{0,5}$ was used, where " $R$ " represents the coronal root canal radius, " $\mathrm{r}$ " the apical root canal radius, and " $h$ " the disc thickness. Debonded specimens were measured under 20x magnification with stereoscope to classify the failure pattern into three types: 1: adhesive failure (between the dentin and the filling material, presenting absence of filling material on the root canal walls); 2 : cohesive failure (presence of filling material on the root canal walls); 3: mixed (failures 1 and 2 may be observed) (figure $1)$.

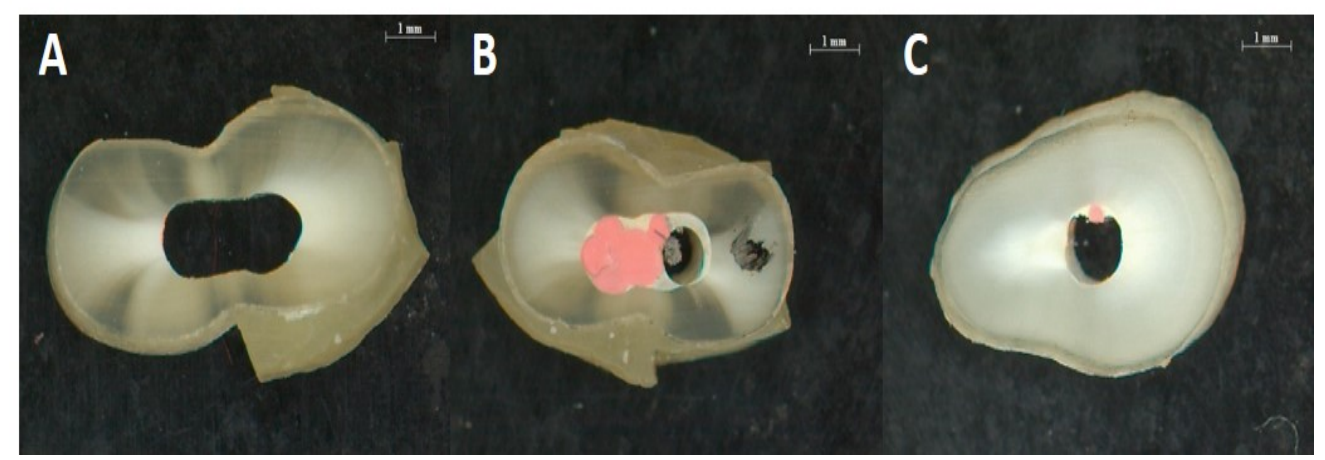

Figure 1. Optical microscopy images illustrating the failure patterns after push-out test - A: adhesive failure; B: cohesive failure; C: mixed failure.

\section{Statistical analysis}


Bacterial reduction and dentin microhardness values were statically analyzed by one-way analysis of variance (ANOVA), followed by post-hoc Tukey test. Bond strength values were statically analyzed by Kruskall-Wallis test, followed by post-hoc Student-Newman-Keuls test. The failure mode distribution was evaluated by the chisquare test. All tests were set at 5\% significance level. Data were analyzed using Stat Plus AnalystSoft Inc. version 6.0 (Vancouver, BC, Canada).

\section{RESULTS}

The mean and standard deviation of $E$. faecalis percentage reduction and dentin microhardness values after intracanal dressing protocols (table 1). The greatest bacterial reduction was observed in $\mathrm{G} 5\left(\mathrm{Ca}[\mathrm{OH}]_{2}+\mathrm{CHX}\right)$ and $\mathrm{G} 6$ $(\mathrm{GSE}+\mathrm{CHX})(\mathrm{p}<0.05)$. There was no statistically significant difference among groups in the dentin microhardness evaluation $(\mathrm{p}<0.05)$.

Table 1. Mean \pm standard deviation of E. faecalis percentage reduction (\%) and dentin microhardness values (Knoop microhardness number) of test intracanal dressing protocols.

$\begin{array}{lll}\text { Groups } & \text { Bacterial reduction (\%) } & \text { Dentin microhar } \\ \text { G1 }(\mathrm{DW}) & 29.32 \pm 1.76^{\mathrm{a}} & 25.83 \pm 4.84^{\mathrm{a}} \\ \mathrm{G} 2(\mathrm{CHX}) & 89.78 \pm 1.99^{\mathrm{b}} & 32.48 \pm 5.41^{\mathrm{a}} \\ \mathrm{G} 3\left(\mathrm{Ca}[\mathrm{OH}]_{2}+\mathrm{DW}\right) & 91.29 \pm 1.43^{\mathrm{b}} & 28.11 \pm 5.74^{\mathrm{a}} \\ \mathrm{G} 4(\mathrm{GSE}+\mathrm{DW}) & 92.96 \pm 2.07^{\mathrm{b}} & 22.85 \pm 4.82^{\mathrm{a}} \\ \mathrm{G} 5\left(\mathrm{Ca}[\mathrm{OH}]_{2}+\mathrm{CHX}\right) & 98.25 \pm 1.28^{\mathrm{c}} & 27.77 \pm 7.02^{\mathrm{a}} \\ \mathrm{G} 6(\mathrm{GSE}+\mathrm{CHX}) & 99.15 \pm 1.14^{\mathrm{c}} & 21.94 \pm 5.31^{\mathrm{a}}\end{array}$

* Data are presented as mean \pm standard deviation. Different index letters represent statistically significant differences in the post hoc procedure (Tukey test); ** DW $=$ distilled water; $\mathrm{CHX}=2 \%$ chlorhexidine gel; $\mathrm{Ca}(\mathrm{OH})_{2}=\mathrm{calcium}$ hydroxide; GSE $=$ grape seed extract; $\mathrm{KMN}=$ Knoop microhardness number.

The bond strength median and percentile values after intracanal dressing protocols and storage periods (table 2). The highest bond strength value in the immediate evaluation was observed in G4 (GSE+DW) and G6 (GSE+CHX), whereas the highest bond strength value after 12 months of storage was observed in G2 (CHX), G3
$\left(\mathrm{Ca}[\mathrm{OH}]_{2}+\mathrm{DW}\right), \quad \mathrm{G} 4 \quad(\mathrm{GSE}+\mathrm{DW}), \quad$ and $\mathrm{G} 6$ $(\mathrm{GSE}+\mathrm{CHX}) \quad(\mathrm{p}<0.05)$. Regarding the failure pattern, high number of adhesive failures was observed in the immediate evaluation and cohesive failures after 12 months of storage, regardless of intracanal dressing protocol $(\mathrm{p}<0.05)$.

Table 2. Median and percentiles $\left(25^{\text {th }}-75^{\text {th }}\right.$ value $)$ of the bond strength of the filling material to root dentin after intracanal dressing protocols and storage periods.

\begin{tabular}{lll}
\hline Groups & $\begin{array}{l}\text { Bond strength (MPa) } \\
\text { Immediate }\end{array}$ & After 12 months \\
\hline $\mathrm{G} 1(\mathrm{DW})$ & $0.74 / 0.34^{\mathrm{A}, \mathrm{a}}$ & $0.21 / 0.14^{\mathrm{A}, \mathrm{b}}$ \\
$\mathrm{G} 2(\mathrm{CHX})$ & $0.51 / 1.02^{\mathrm{A}, \mathrm{a}}$ & $2.94 / 2.05^{\mathrm{B}, \mathrm{b}}$ \\
$\mathrm{G} 3\left(\mathrm{Ca}[\mathrm{OH}]_{2}+\mathrm{DW}\right)$ & $1.19 / 1.41^{\mathrm{A}, \mathrm{a}}$ & $2.60 / 2.17^{\mathrm{B}, \mathrm{b}}$ \\
$\mathrm{G} 4(\mathrm{GSE}+\mathrm{DW})$ & $2.59 / 2.59^{\mathrm{B}, \mathrm{a}}$ & $3.00 / 1.05^{\mathrm{B}, \mathrm{a}}$ \\
$\mathrm{G} 5\left(\mathrm{Ca}[\mathrm{OH}]_{2}+\mathrm{CHX}\right)$ & $0.69 / 0.61^{\mathrm{A}, \mathrm{a}}$ & $0.62 / 0.72^{\mathrm{C}, \mathrm{a}}$ \\
$\mathrm{G} 6(\mathrm{GSE}+\mathrm{CHX})$ & $2.98 / 2.90^{\mathrm{B}, \mathrm{a}}$ & $2.80 / 1.85^{\mathrm{B}, \mathrm{a}}$ \\
\hline
\end{tabular}

* Data are presented as median and percentiles. Different superscript index letters represent statistically significant differences in the column; different lower script index letters represent statistically significant differences in the row $(\mathrm{p}<0.05) ; * * \mathrm{DW}=\mathrm{distilled}$ water; $\mathrm{CHX}=2 \%$ chlorhexidine gel; $\mathrm{Ca}(\mathrm{OH})_{2}=$ calcium hydroxide; $\mathrm{GSE}=$ grape seed extract; $\mathrm{MPa}=$ megapascals.

\section{DISCUSSION}

The use of intracanal dressings results in improved microbiological and structural status of the root canal system (VERA et al., 2012), and adequate tests are necessary to evaluate their properties. The counting of CFUs provides bacterial quantification of root canals in an acceptable way, allowing calculating the E. faecalis percentage reduction (PETERS; WESSELINK; MOORER, 1995; MATOS et al., 2019). The Knoop test is more sensitive to surface conditions and, due to its longer diagonals, it is less sensitive to measure errors when equal loads are applied (LYSAGHT; DEBELLIS, 1969). The push-out test is compatible with the clinical situation, produces effective power for 
Effectiveness...

material displacement and induces less stress at the bond interface during disc preparation (HUFFMAN et al., 2009). Thus, the present study used these tests, in order to evaluate the use of GSE-based intracanal dressings against E. faecalis and its influence on dentin microhardness and bond strength of the filling material.

The antimicrobial mechanism of $\mathrm{Ca}(\mathrm{OH})_{2}$ is known to be dependent on the dissociation and diffusion of hydroxyl ions, elevating $\mathrm{pH}$ and inhibiting enzymatic activities (LEONARDO et al., 2006). Previous studies have reported that 14-21 days are necessary to obtain elevated $\mathrm{pH}$ and effective antimicrobial activity of $\mathrm{Ca}(\mathrm{OH})_{2}$ (LEONARDO et al., 2006). In addition, due to microbial resistance, some studies suggested the addition of $\mathrm{CHX}$ to $\mathrm{Ca}(\mathrm{OH})_{2}$-based intracanal dressings, in order to improve antimicrobial activity (GOMES et al., 2006; SIGNORETTI et al., 2011). 14 days of maintenance in root canals and the addition of CHX to test intracanal dressings were adopted in the present study.

Intracanal dressings have effective action against inflammatory contents of root canals with primary infections (MARTINHO et al., 2018) and primary periodontal lesions with secondary endodontic involvement (DUQUE et al., 2019). The present results showed that GSE-based intracanal dressings (groups G4 and G6) were as effective as $\mathrm{Ca}(\mathrm{OH})_{2}$-based intracanal dressings in reducing the count of the E. faecalis, confirming the first hypothesis (i) of the present study. These findings are in accordance with previous studies, where the use of GSE showed effective bacterial reduction in root canals (CECCHIN et al., 2015; SOUZA et al., 2017). GSE is a natural product composed of PACs, which is structurally formed by flavonols. These polyphenolic components present antimicrobial activity against gram-positive bacteria, acting in structural components of the bacterial cell wall (FURIGA; ROQUES; BADET, 2014). It may help to explain the satisfactory results of GSE-based intracanal dressings in the reduction of E. faecalis, after 14 days in the root canal.

CHX is a cationic bisguanide that binds to the cell wall of the microorganism and causes the leakage of intracellular components (DAMETTO et al., 2005). The addition of CHX to test intracanal dressings revealed higher reduction in the count of E. faecalis, being in accordance with previous studies that obtained similar results with the addition of $2 \% \quad \mathrm{CHX}$ to intracanal dressings (GOMES et al., 2006; SIGNORETTI et al., 2011). The antimicrobial mechanism occurs by the interaction between $\mathrm{CHX}$ molecules (positively
SOUZA, M. A. et al.

charged) and bacterial cellular wall (negatively charged). Then, CHX induces changes in cellular osmotic equilibrium, resulting in the precipitation of cytoplasmic content and the death of microorganisms (DAMETTO et al., 2005). Therefore, the antimicrobial properties of test intracanal dressings and CHX may explain the greater reduction in the count of E. faecalis in these groups.

Dentin discs are usually obtained by transversal cuts from the roots of human teeth, in order to investigate the effects of chemical substances on dentin microhardness (SAYIN et al., 2007). In these cases, the dentin surface is covered by the chemical substance and the microhardness is measured after this protocol. However, the intracanal dressing contact is initially with the most superficial dentin layer of the root canal lumen and then diffuses through dentinal tubules (SLUTZKYGOLDBERG et al., 2004). Thus, the present study adopted the same methodology of Slutzky-Goldberg et al. (2004), where roots are filled with the chemical substance for a period of time, being longitudinally split to measure the microhardness in the pulp-dentin interface. This procedure seems closer to a clinical situation, providing better approach regarding the effects of test intracanal dressings on dentin structure.

$\mathrm{Ca}(\mathrm{OH})_{2}$-based intracanal dressings can lead to physical changes on dentin structure, since they promote denaturation of the root dentin collagen matrix. It is caused by the low molecular weight and highly alkaline $\mathrm{pH}$ of $\mathrm{Ca}(\mathrm{OH})_{2}$ (LEIENDECKER et al., 2012). On the other hand, the results of present study revealed that GSE-based intracanal dressings did not influence the dentin microhardness values, being similar to control group and $\mathrm{Ca}(\mathrm{OH})_{2}$ groups, regardless of CHX addition. The second hypothesis (ii) of this study is then confirmed. Extracts rich in PACs improve dentin mechanical properties due to their highly stable interaction with dentinal collagen. It occurs by the formation of hydrogen bonds between the protein amide carbonyl and the phenolic hydroxyl group of the polyphenol associated with covalent and hydrophobic bonds. Covalent-like bonds resulted from this interaction can help preserving the dentin structure (BEDRANRUSSO et al., 2014).

According to the results obtained in the immediate evaluation, the highest bond strength values were observed in groups treated with GSEbased intracanal dressings, regardless of $\mathrm{CHX}$ addition. After 12 months, bond strength values were maintained in these groups. The third hypothesis (iii) of this study was then confirmed. 
Effectiveness...

Cecchin et al. (2015) showed that GSE preserves the bond strength of fiber posts to root dentin for 12 months, improving bond strength stability of dentin-adhesive interfaces in root canals. PACs present in its composition preserves the mechanical properties (CECCHIN et al., 2015) and stabilizes the dentin collagen degradation (AGUIAR et al., 2014). It contributes to the maintenance of dentinal substrates for satisfactory bond strength of resinbased filling materials and prevents microbial leakage, creating a favorable environment for regeneration in the periapical region (AGUIAR et al., 2014).

After 12 months of storage, the bond strength values decreased in the control group, where intracanal dressing protocol was not performed. On the other hand, the bond strength values increased in $\mathrm{G} 2(\mathrm{CHX})$ and $\mathrm{G} 3\left(\mathrm{Ca}[\mathrm{OH}]_{2}\right)$. The use of CHX does not interfere with collagen present in the organic matrix of the root dentin (MOREIRA et al., 2009). Similarly, $\mathrm{Ca}(\mathrm{OH})_{2}$ residues have a positive effect on the dislodgement resistance of root canal sealers (AMIN; SEYAM;
SOUZA, M. A. et al.

EL-SAMMAN, 2012). It contributed to increase the bond strength values in these groups. In addition, the present results showed higher number of adhesive failures in the immediate evaluation and cohesive failures after 12 months of storage. $\mathrm{AH}$ Plus epoxy-resin-based endodontic sealer has high flowability and long polymerization time. Moreover, cohesion among AH Plus molecules increases the displacement resistance of the filling material in the root dentin over time, providing greater adhesion (SILVA et al., 2016). It helped to explain the present results regarding the failure pattern.

\section{CONCLUSIONS}

Despite the limitations of the present study, it was possible to conclude that GSE-based intracanal dressings have antimicrobial potential against E. faecalis, do not influence dentin microhardness and preserve the high bond strength of the filling material to root dentin over time.

RESUMO: O objetivo deste estudo foi avaliar a eficácia de medicamentos intracanal à base de extrato de semente de uva (GSE) contra Enterococcus faecalis (E. faecalis) e sua influência na microdureza da dentina e na resistência de união do material de obturação. Os canais radiculares de 126 dentes humanos foram distribuídos em três grupos de teste: atividade antimicrobiana (60 dentes), microdureza da dentina (30 dentes) e resistência adesiva (36 dentes). Nos três grupos, as amostras foram subdivididas em seis grupos, de acordo com os protocolos de curativos intracanal: G1 - água destilada (DW); G2 - gel de clorexidina a 2\% (CHX); G3 hidróxido de cálcio $\left(\mathrm{Ca}[\mathrm{OH}]_{2}\right)+\mathrm{DW}$; G4 - GSE+DW; G5 - $\mathrm{Ca}(\mathrm{OH})_{2}+\mathrm{CHX}$; G6 - GSE+CHX. A contagem de unidades formadoras de colônias (UFCs), o testador de microdureza Vickers e o teste push-out foram realizados para avaliar a atividade antimicrobiana, a microdureza da dentina e a resistência adesiva, respectivamente. Análise estatística específica foi realizada para cada avaliação $(\alpha=5 \%)$. A maior redução bacteriana foi observada no G5 $\left(\mathrm{Ca}[\mathrm{OH}]_{2}+\mathrm{CHX}\right)$ e $\mathrm{G} 6(\mathrm{GSE}+\mathrm{CHX})(\mathrm{p}<0,05)$. Não houve diferença estatisticamente significativa entre os grupos na avaliação da microdureza da dentina $(\mathrm{p}<0,05)$. A maior resistência adesiva na avaliação imediata foi observada no G4 (GSE+DW) e G6 (GSE+CHX), enquanto a maior resistência adesiva após 12 meses de armazenamento foi observada no G2 (CHX), G3 $\left(\mathrm{Ca}[\mathrm{OH}]_{2}+\mathrm{DW}\right), \mathrm{G} 4(\mathrm{GSE}+\mathrm{DW})$ e G6 $(\mathrm{GSE}+\mathrm{CHX})(\mathrm{p}<0,05)$. Após o período de armazenamento, a resistência de união aumentou no G2 (CHX) e G3 $\left(\mathrm{Ca}[\mathrm{OH}]_{2}+\mathrm{DW}\right)$, permanecendo inalterada no G4 $(\mathrm{GSE}+\mathrm{DW})$ e $\mathrm{G} 6(\mathrm{GSE}+\mathrm{CHX})(\mathrm{p}<0,05)$. Os medicamentos intracanal à base de GSE têm potencial antimicrobiano contra E. faecalis, não influenciam na microdureza da dentina e preservam a alta resistência adesiva dos materiais de obturação da dentina radicular ao longo do tempo.

PALAVRAS-CHAVE: Atividade antimicrobiana. Extrato de semente de uva. Medicação intracanal. Microdureza. Resistência de união.

\section{REFERENCES}

AGUIAR, T.R.; VIDAL, C.M.; PHANSALKAR, R.S.; TODOROVA, I.; NAPOLITANO, J.G.; MCALPINE, J.B. et al. Dentin biomodification potential depends on polyphenol source. Journal of Dental Research, v. 93, n. 4, p. 417-422, 2014. http://dx.doi: 10.1177/0022034514523783 
AMIN, S.A.; SEYAM, R.S.; EL-SAMMAN, M.A. The effect of prior calcium hydroxide intracanal placement on the bond strength of two calcium silicate-based and an epoxy resin based endodontic sealer. The Journal of Endodontics, v. 38, n. 5, p. 696-699, 2012. http://dx.doi: 10.1016/j.joen.2012.02.007

BEDRAN-RUSSO, A.K.; PAULI, G.F.; CHEN, S.N.; MCALPINE, J.; CASTELLAN, C.S.; PHANSALKAR, R.S. et al. Dentin biomodification: strategies, renewable resources and clinical applications. Dental Materials, v. 30, n. 1, p. 62-76, 2014. http://dx.doi: 10.1016/j.dental.2013.10.012

CECCHIN, D.; FARINA, A.P.; SOUZA, M.A.; ALBARELLO, L.L.; SCHNEIDER, A.P.; VIDAL, C.M.; BEDRAN-RUSSO, A.K. Evaluation of antimicrobial effectiveness and dentine mechanical properties after use of chemical and natural auxiliary irrigants. Journal of Dentistry, v. 43, n. 6, p. 695-702, 2015. http://dx.doi: 10.1016/j.jdent.2015.03.013

DAMETTO, F.R.; FERRAZ, C.C.; GOMES, B.P.; ZAIA, A.A.; TEIXEIRA, F.B.; SOUZA-FILHO, F.J. In vitro assessment of the immediate and prolonged antimicrobial action of chlorhexidine gel as an endodontic irrigant against Enterococcus faecalis. Oral Surgery, Oral Medicine, Oral Pathology and Oral Radiology and Endodontics, v. 99, n. 6, p. 768-772, 2005. http://dx.doi: 10.1016/j.tripleo.2004.08.026

DUQUE, T.M.; PRADO, M.; HERRERA, D.R.; GOMES, B.P.F.A. Periodontal and endodontic infectious/inflammatory profile in primary periodontal lesions with secondary endodontic involvement after a calcium hydroxide-based intracanal medication. The Journal Clinical Oral Investigations, v. 23, n. 1, p. 5363, 2019. http://dx.doi: 10.1007/s00784-018-2401-6

FURIGA, A.; ROQUES, C.; BADET, C. Preventive effects of an original combination of grape seed olyphenols with amine fluoride on dental biofilm formation and oxidative damage by oral bacteria. Journal of Applied Microbiology, v. 116, n. 4, p. 761-771, 2014. http://dx.doi: 10.1111/jam.12395

GOMES, B.P.; VIANNA, M.E.; SENA, N.T.; ZAIA, A.A.; FERRAZ, C.C.; SOUZA-FILHO, F.J. In vitro evaluation of the antimicrobial activity of calcium hydroxide combined with chlorhexidine gel used as intracanal medicament. Oral Surgery, Oral Medicine, Oral Pathology, Oral Radiology and Endodontics, v. 102, n. 4, p. 544-550, 2006. http://dx.doi: 10.1016/j.tripleo.2006.04.010

GUIOTTI, F.A.; KUGA, M.C.; DUARTE, M.A.; SANT'ANNA, A.J.; FARIA, G. Effect of calcium hydroxide dressing on push-out bond strength of endodontic sealers to root canal dentin. Brazilian Oral Research, v. 28, n.1, p. 1-6, 2014. http://dx.doi: 10.1590/S1806-83242014.50000002

HUFFMAN, B.P.; MAI, S.; PINNA, L.; WELLER, R.N.; PRIMUS, C.M.; GUTMANN, J.L. et al. Dislocation resistance of ProRoot Endo Sealer, a calcium-silicate-based root canal sealer, from radicular dentine.

International Endodontic Journal, v. 42, n. 1, p. 34-46, 2009. http://dx.doi: 10.1111/j.1365-

2591.2008.01490.x

LEIENDECKER, A.P.; QI, Y.P.; SAWYER, A.N.; NIU, L.N.; AGEE, K.A.; LOUSHINE, R.J. et al. Effects of calcium silicate-based materials on collagen matrix integrity of mineralized dentin. The Journal

of Endodontics, v. 38, n. 6, p. 829-833, 2012. http://dx.doi: 10.1016/j.joen.2012.01.004

LEONARDO, M.R.; HERNANDEZ, M.E.; SILVA, L.A.; TANOMARU-FILHO, M. Effect of a calcium hydroxide-based root canal dressing on periapical repair in dogs: a histological study. Oral Surgery, Oral Medicine, Oral Pathology, Oral Radiology and Endodontics, v. 102, n. 5, p. 680-685, 2006. http://dx.doi: 10.1016/j.tripleo.2006.03.021

LYSAGHT, V.E.; DEBELLIS, A. Microhardness testing. In: WILKES, B., ed. Hardness testing handbook. New York: American Chain and Cable Co; 1969:76-105. 
MARTINHO, F.C.; GOMES, C.C.; NASCIMENTO, G.G.; GOMES, A.P.M.; LEITE, F.R.M. Clinical comparison of the effectiveness of 7- and 14-day intracanal medications in root canal disinfection and inflammatory cytokines. The Journal Clinical Oral Investigations, v. 22, n. 1, p. 523-530, 2018. http://dx.doi: 10.1007/s00784-017-2143-x

MATOS, F.S.; KHOURI, R.D.; CARVALHO, C.A.T.; MARTINHO, F.C.; BRESCIANI, E.; VALERA, M.C. Effect of EDTA and QMIX Ultrasonic Activation on the Reduction of Microorganisms and Endotoxins in Ex Vivo Human Root Canals. Brazilian Dental Journal, v. 30, n. 3, p. 220-226, 2019. http://dx.doi: 10.1590/0103-6440201902470.

MOREIRA, D.M.; ALMEIDA, J.F.; FERRAZ, C.C.; GOMES, B.P.; LINE, S.R.; ZAIA, A.A. Structural analysis of bovine root dentin after use of different endodontics auxiliary chemical substances. The Journal of Endodontics, v. 35, n. 7, p. 1023-1027, 2009. http://dx.doi: 10.1016/j.joen.2009.04.002

PETERS, L.B.; WESSELINK, P.R.; MOORER, W.R. The fate and the role of bacteria left in root dentinal tubules. International Endodontic Journal, v. 28, n. 2, p. 95-99, 1995. http://dx.doi: 10.1111/j.13652591.1995.tb00166.x

SATHORN, C.; PARASHOS, P.; MESSER, H. Antibacterial efficacy of calcium hydroxide intracanal dressing: a systematic review and meta-analysis. International Endodontic Journal, v. 40, n. 1, p. 2-10, 2007. http://dx.doi: 10.1111/j.1365-2591.2006.01197.x

SAYIN, T.C.; SERPER, A.; CEHRELI, Z.C.; OTLU, H.G. The effect of EDTA, EGTA, EDTAC and tetracycline- $\mathrm{HCl}$ with and without subsequent $\mathrm{NaOCl}$ treatment on the microhardness of root canal dentin.

Oral Surgery, Oral Medicine, Oral Pathology, Oral Radiology and Endodontics, v. 104, n. 3, p. 418-424, 2007. http://dx.doi: 10.1016/j.tripleo.2007.03.021

SIGNORETTI, F.G.; GOMES, B.P.; MONTAGNER, F.; BARRICHELLO TOSELLO, F.; JACINTO, R.C. Influence of $2 \%$ chlorhexidine gel on calcium hydroxide ionic dissociation and its ability of reducing endotoxin. Oral Surgery, Oral Medicine, Oral Pathology, Oral Radiology and Endodontics, v. 111, n. 5, p. 653-658, 2011. http://dx.doi: 10.1016/j.tripleo.2010.11.016

SILVA, E.J.; CARVALHO, N.K.; PRADO, M.C.; ZANON, M.; SENNA, P.M.; SOUZA, E.M.; DE-DEUS, G. Push-out bond strength of injectable pozzolan-based root canal sealer. The Journal of Endodontics, v. 42, n. 11, p. 1656-1659, 2016. http://dx.doi: 10.1016/j.joen.2016.08.009

SIQUEIRA, J.F. JR.; RÔÇAS, I.N.; LOPES, H.P.; DE UZEDA, M. Coronal leakage of two root canal sealers containing calcium hydroxide after exposure to human saliva. The Journal of Endodontics, v. 25, n. 1, p. 14 16, 1999. http://dx.doi: 10.1016/s0099-2399(99)80391-4

SLUTZKY-GOLDBERG, I.; MAREE, M.; LIBERMAN, R.; HELING, I. Effect of sodium hypochlorite on dentin microhardness. The Journal of Endodontics, v. 30, n. 12, p. 880-882, 2004.

https://doi.org/10.1097/01.DON.0000128748.05148.1E

SOUZA, M.A.; DALLA-LANA, D.; GABRIELLI, E.; RIBEIRO, M.B.; MIYAGAKI, D.C.; CECCHIN, D. Effectiveness of final decontamination protocols against Enterococcus faecalis and its influence on bond strength of filling material to root canal dentin. Photodiagnosis and Photodynamic Therapy, v. 17, n.1, p. 9297, 2017. http://dx.doi: 10.1016/j.pdpdt.2016.11.004

SOUZA, M.A.; TUMELERO, C.D.; ZANDONÁ, J.; HOFFMANN, I.P.; MENCHIK, V.H.S.; PALHANO, H.S. et al. Antimicrobial activity of hypochlorite solutions and reciprocating instrumentation associated with photodynamic therapy on root canals infected with Enterococcus faecalis - An in vitro study.

Photodiagnosis and Photodynamic Therapy, v. 23, n.1, p. 347-352, 2018. http://dx.doi: 10.1016/j.pdpdt.2018.07.015 
TENNERT, C.; FUHRMANN, M.; WITTMER, A.; KARYGIANNI, L.; ALTENBURGER, M.J.; PELZ, K.; et al. New bacterial composition in primary and persistent/secondary endodontic infections with respect to clinical and radiographic findings. The Journal of Endodontics, v. 40, n. 5, p. 670-677, 2014. http://dx.doi: 10.1016/j.joen.2013.10.005

VAUDT, J.; BITTER, K.; NEUMANN, K.; KIELBASSA, A.M. Ex vivo study on root canal instrumentation of two rotary nickel-titanium systems in comparison to stainless steel hand instruments. International Endodontic Journal, v. 42, n. 1, p. 22-33, 2009. http://dx.doi: 10.1111/j.1365-2591.2008.01489.x

VERA, J.; SIQUEIRA, J.F. JR.; RICUCCI, D.; LOGHIN, S.; FERNÁNDEZ, N.; FLORES, B. et al. Oneversus two-visit endodontic treatment of teeth with apical periodontitis: a histobacteriologic study. The Journal of Endodontics, v. 38, n. 8, p. 1040-1052, 2012. http://dx.doi: 10.1016/j.joen.2012.04.010

VIDAL, C.M.; AGUIAR, T.R.; PHANSALKAR, R.; MCALPINE, J.B.; NAPOLITANO, J.G.; CHEN, S.N. et al. Galloyl moieties enhance the dentin biomodification potential of plant-derived catechins. Acta Biomaterialia, v. 10, n. 7, p. 3288-3294, 2014. http://dx.doi: 10.1016/j.actbio.2014.03.036

YASSEN, G.H.; VAIL, M.M.; CHU, T.G.; PLATT, J.A. The effect of medicaments used in endodontic regeneration on root fracture and microhardness of radicular dentine. International Endodontic Journal, v. 46, n. 7, p. 688-695, 2013. http://dx.doi: 10.1111/iej.12046 